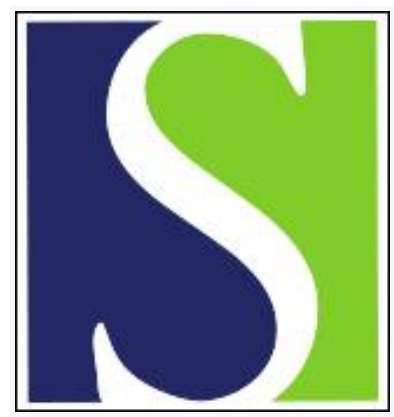

Scand J Work Environ Health 2014;40(3):295-304

https://doi.org/10.5271/sjweh.3414

Published online: 08 Jan 2014, Issue date: 01 May 2014

Rotating-shift nurses after a day off: peripheral clock gene expression, urinary melatonin, and serum 17 - $\beta$-estradiol levels

by Bracci M, Manzella N, Copertaro A, Staffolani S, Strafella E, Barbaresi M, Copertaro B, Rapisarda V, Valentino M, Santarelli L

Altered levels of peripheral clock gene expression and higher levels of 17-beta-estradiol levels were found among shift workers sampled at the beginning of the morning shift after a regular night's sleep on a day off. These findings, and their relation with chronotype, supplement information to the potential biological processes underlying the increased risk of breast cancer among shift workers.

Affiliation: Occupational Medicine, Department of Clinical and Molecular Sciences, Polytechnic University of Marche, Via Tronto 10/a, 60020 Torrette, Ancona, Italy.m.bracci@univpm.it

Refers to the following texts of the Journal: $2010 ; 36(2): 134-141$

2010;36(2):163-179 2012;38(4):380-390 2012;38(4):327-336

2012;38(6):553-559 2013;39(2):170-177 2013;39(5):448-455

The following articles refer to this text: 2015;41(1):105-106; 2016;42(5):435-446

Key terms: 6-sulfatoxymelatonin; breast cancer; chronotype; circadian rhythm; clock gene; clock gene expression; night work; nurse; peripheral clock gene expression; rotating shift; serum 17- $\beta$-estadiol; shift work; shift worker; urinary melatonin; work schedule tolerance

This article in PubMed: www.ncbi.nlm.nih.gov/pubmed/24402410

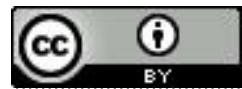




\title{
Rotating-shift nurses after a day off: peripheral clock gene expression, urinary melatonin, and serum 17- $\beta$-estradiol levels
}

\author{
By Massimo Bracci, MD, PhD, ${ }^{1}$ Nicola Manzella, MSc, ${ }^{1}$ Alfredo Copertaro, MD, ${ }^{2}$ Sara Staffolani, PhD, ${ }^{1}$ \\ Elisabetta Strafella, PhD, ${ }^{1}$ Mariella Barbaresi, RN, ${ }^{2}$ Benedetta Copertaro, MSc, ${ }^{2}$ Venerando Rapisarda, \\ MD, PhD, ${ }^{3}$ Matteo Valentino, MD, PhD, ${ }^{1}$ Lory Santarelli MD, PhD ${ }^{1}$
}

Bracci M, Manzella N, Copertaro A, Staffolani S, Strafella E, Barbaresi M, Copertaro B, Rapisarda V, Valentino M, Santarelli L. Rotating-shift nurses after a day off: peripheral clock gene expression, urinary melatonin, and serum 17- $\beta$-estradiol levels. Scand J Work Environment Health. 2014;40(3):295-304. doi:10.5271/sjweh.3414

Objective Impairment of clock gene expression and changes in melatonin and 17- $\beta$-estradiol levels may constitute biological alterations underlying the increased risk of breast cancer among shift workers. The aim of this study was to compare levels of selected core clock gene expression, 6-sulfatoxymelatonin (aMT6s), and $17-\beta$-estradiol between rotational shift work (SW) and daytime (DT) workers after a day off.

Methods The cross-sectional study comprised 60 nurses with $\geq 2$ years of SW and 56 permanent DT nurses. Transcript levels of circadian genes BMAL1, CLOCK, NPAS2, CRY1, CRY2, PER1, PER2, PER3, and REVERBo were determined by quantitative real-time polymerase chain reaction (PCR) in lymphocytes. All participants were tested in the early follicular phase of the menstrual cycle. Samples were collected at the beginning of the morning-shift after a regular night's sleep on a day off. Chronotype and sociodemographic characteristics were also evaluated.

Results We found a significantly higher expression of BMAL1, CLOCK, NPAS2, PER1, PER2, and REVERB $\alpha$ and a lower expression of PER3, CRY1 and CRY2 among SW compared to DT nurses. SW participants did not demonstrate a significant difference in aMT6s levels, but they did show significantly higher 17- $\beta$-estradiol levels compared to DT nurses. Multiple linear regression analysis confirmed the role of SW on expression of BMAL1 ( $\beta 0.21$, $\mathrm{P}=0.040), C L O C K(\beta 0.35, \mathrm{P}=0.008)$, NPAS2 ( $\beta 0.30, \mathrm{P}=0.012)$, PERI ( $\beta$ 0.33, $\mathrm{P}=0.008)$, PER2 ( $\beta$ 0.19, $\mathrm{P}=0.047)$, $\operatorname{PER} 3(\beta-0.27, \mathrm{P}=0.012), C R Y 1(\beta-0.33, \mathrm{P}=0.002), C R Y 2(\beta-0.31, \mathrm{P}=0.005), \operatorname{REVERB} \alpha(\beta 0.19, \mathrm{P}=0.045)$, and on $17-\beta$-estradiol levels $(\beta 0.32, \mathrm{P}=0.003)$. The analysis also confirmed the role of chronotype as an independent factor for PERI $(\beta 0.48, \mathrm{P}=0.001)$ and PER2 ( $\beta-0.22, \mathrm{P}=0.022)$ expression, and 17- $\beta$-estradiol levels $(\beta \quad 0.26, \mathrm{P}=0.011)$.

Conclusions Rotating SW nurses show alterations in peripheral clock gene expression and 17- $\beta$-estradiol levels at the beginning of the morning shift after a day off.

Key terms aMT6s; breast cancer; chronotype; circadian rhythm; night work; shift work; shift worker; work schedule tolerance; 6-sulfatoxymelatonin

Shift work may be associated with a desynchronization of internal rhythms from the external environment resulting in compromised circadian physiological processes (1-5). The International Agency for Research on Cancer (IARC) has classified shift work that results in circadian disruption as probably carcinogenic to humans (6). Several epidemiological studies have found that shift work involving night work may result in an increased risk of breast cancer (7-17). Although the biological mechanisms underlying increased risk of cancer among night-shift workers have not been fully understood, some mechanisms have been proposed. Disruption of the circadian rhythms primarily induced by light exposure at night, as experienced by shift workers, may alter circadian expression of clock genes $(2,18)$. The master clock is located in the hypothalamic supra-

1 Occupational Medicine, Department of Clinical and Molecular Sciences, Polytechnic University of Marche, Ancona, Italy.

2 Healthcare Workers Service, ASUR area 2, Loreto Hospital, Loreto, Italy.

3 Section of Occupational Medicine, Department of Internal Medicine and Systemic Diseases, University of Catania, Catania, Italy.

Correspondence to: Massimo Bracci, Occupational Medicine, Department of Clinical and Molecular Sciences, Polytechnic University of Marche, Via Tronto 10/a, 60020 Torrette, Ancona, Italy. [E-mail: m.bracci@univpm.it] 
chiasmatic nucleus and can be set by environmental cues such as light (19). Peripheral clocks are present in almost all other mammalian tissues such as liver, heart, lung, and kidney, where they maintain circadian rhythms and regulate tissue-specific gene expression (20). These peripheral clocks are synchronized by the master clock to ensure temporally coordinated physiology.

Clock gene expression of master and peripherals clocks is regulated by several interconnected feedback loops (21-22). The main autoregulatory feedback loop is regulated by both positive and negative components. The positive regulators are the heterodimers BMAL1/ $C L O C K$ and BMAL1/NPAS2. The negative arm is formed by PER1, PER2, PER3, CRY1, and CRY2. PER and $C R Y$ proteins translocate into the nucleus and form a complex to inhibit transcriptional activity of BMAL1/ $C L O C K$ or $B M A L 1 / N P A S 2$ in a negative feedback loop. In an additional loop, REVERB $\alpha$ represses the BMAL1 gene expression (21-22). Since circadian clock genes are involved in cell proliferation, apoptosis, and DNA damage response, alteration in some core clock gene expression may be associated with carcinogenic processes (23-27). Moreover adaptability of the workers to a specific shift may be influenced by an individual chronotype that was suggested to be related to clock genes (28-30). Subjects with morning chronotype, resulting in morning preference, are less adaptable to shift work $(31,32)$. Shift workers with this diurnal preference may have a higher risk of breast cancer (33).

Light exposure at night and sleep deprivation influence circulating levels of melatonin, a hormone with direct oncostatic properties, and levels of reproductive hormones, thus resulting in increased risk of breast cancer (27, 34-39). Among shift workers, melatonin secretion was found to be strongly influenced by the number of night shifts, specific work schedule, and light intensity exposure during night shifts (40-46). Davis and co-workers found decreased aMT6s levels among nurses working $\geq 20$ hours/week during the graveyard shift (47); Hansen and co-workers (48) obtained similar results. On the other hand, Grundy and co-workers found that two nights of shift work did not change the timing of melatonin production (49).

The association of shift work and levels of reproductive hormones is still a matter of debate since varied findings were obtained by previous studies $(46,47,50$, 51). Schernhammer and co-workers found a significant increase of estradiol levels only after long durations of night work ( $>15$ years) among postmenopausal women (46). Davis and co-workers (47) did not observe a difference in estron levels between shift and daytime workers, while Nagata and co-workers (51) observed significantly increased estron - but not estradiol levels - among shift workers.

This cross-sectional study was conducted to deter- mine the effects of rotating shift work on the expression of selected peripheral circadian genes and urinary 6-sulfatoxymelatonin (aMT6s) and serum 17- $\beta$-estradiol levels. In order to prevent findings of acute alterations associated with the night shift, the effects of rotating shift work were evaluated after a day off.

\section{Methods}

\section{Participants and sampling}

All participants were female nurses of the National Health Service (NHS) hospital wards in Ancona (Italy) undergoing their periodic health monitoring in JanuaryJune 2012. Of the 184 female registered nurses, 82 were shift work (SW) and 102 were daytime (DT) nurses. SW nurses were employed in a "clockwise rapidly rotating" type of shift and the schedule was as follows: day 1: 07:00-14:00 hours; day 2: 14:00-22:00 hours; day 3: 22:00-07:00 hours; 48 hours of rest; resumption of the cycle. The work schedule of DT nurses was 07:00-14:00 hours six days/week.

Nurses were evaluated and selected based on the following criteria: fertile age (presence of a menstrual cycle); no current treatment with drugs; a negative history of psychiatric disorders, degenerative or cardiovascular diseases, insomnia, chronic viral infections, tumor or autoimmune diseases, or conditions such as fibromatosis of the uterus and polycystic ovary; no occupational exposure to ionizing radiation or involvement in antiblastic drug preparation; and absence of artificial light when sleeping at home. Additional selection criteria were taken into account for SW and DT nurses. SW nurses had to be assigned for $\geq 2$ years to the current shift schedule involving $\geq 60$ night shifts/year without schedule breaks in the previous 6 months. DT nurses had to have a habitual sleep/wake schedule between approximately 23:00-06:00 hours with no episode of sleep deprivation for $\geq 3$ weeks prior to the study. On the bases of selection criteria, 60 SW and 56 DT nurses were enrolled. The study was carried out in accordance with the Declaration of Helsinki's ethical standards. Being part of the standard occupational health surveillance, the study needed no formal approval by the local ethics committee. Nevertheless, the committee was consulted and an informal authorization was granted. All subjects agreed to participate in the study and gave their informed written consent.

The samples from nurses in both SW and DT groups were taken at the beginning of the morning shift after a regular night's sleep on a day off. All participants selfreported to be in the early follicular phase (between the $2^{\text {nd }}$ and $5^{\text {th }}$ day of the menstrual cycle). During this menstrual phase, stable estrogen levels allowed for 
equal comparisons between groups $(52,53)$. Participants completed a questionnaire regarding their work schedule, sleep quality according to the Pittsburgh Sleep Quality Index (PSQI) (54), reproductive physiology, physical activity, and other habits such as smoking and alcohol consumption. Chronotype was assessed by the "Morningness-Eveningness Questionnaire" (MEQ) (55), a 19-item questionnaire with a total score ranging from 16-86 extensively used among adults and workers (56-59). Samples of fasting blood (8 hours) were collected at 07:00 hours and were processed immediately after collection to prevent a possible extracorporeal clock gene induction. Blood samples were divided into two aliquots: one for lymphocyte separation and another for serum $17-\beta$-estradiol quantification.

Urine samples consisted of urine that participants had collected in a container between 23:00-07:00 hours and handed over to the laboratory at 07:00 hours. After delivery, urine samples were stored at $-80^{\circ} \mathrm{C}$ until aMT6s and creatinine analysis.

\section{Expression of clock genes}

Immediately after blood sampling, lymphocytes were isolated using a density gradient separation medium (Cedarlane Laboratories LTD, Hornby, Ontario, Canada) and stored at $-80^{\circ} \mathrm{C}$ until RNA extraction. The isolation of total RNA was performed using the Vantage Total RNA Purification Kit (Origene, Rockville, MD, USA) according to the manufacturer's instructions. RNA quality and quantification were evaluated with a Nanodrop 1000 spectrophotometer (Thermo Scientific, Wilmington, DE, USA). cDNA was synthesized according to the of High-Capacity cDNA Reverse Transcription Kit protocol (Applied Biosystems, Foster City, CA, USA). The clock genes investigated were: BMAL1, CLOCK, NPAS2, PER1, PER2, PER3, CRY1, CRY2, and REVERB $\alpha$.

Gene expression was analyzed by real-time quantitative polymerase chain reaction (PCR) using the TaqMan Gene Expression Master Mix (Applied Biosystems, Foster City, CA, USA). Specific primer sets were obtained from IDT (Integrated DNA Technologies Inc, Coralville, IA, USA). To control variations in the amount of cDNA available for PCR in the different samples, the gene expression levels of the target sequences were normalized to the expression of an endogenous control, glyceraldehyde-3-phosphate dehydrogenase (GAPDH). The expression levels of clock genes were calculated by applying the following equation: $2^{-\Delta \mathrm{Ct}}$.

\section{Hormone assay}

A primary metabolite of melatonin in urine, aMT6s was tested. It has been recognized as a valid predictor of overnight or peak melatonin synthesis $(60,61)$ and used in other cross sectional studies $(62,63)$. Furthermore the correlation of aMT6s excretion with plasma melatonin is highest during follicular phase of a woman's cycle (64-66).

aMT6s was assayed using DRG Melatonin-Sulfate (DRG International Inc, Mountainside, NJ, USA), a commercially available solid-phase competitive ELISA kit. Variations in urine diluteness were taken into account by measuring the urinary creatinine level and aMT6s levels were expressed as aMT6s/creatinine. Urinary creatinine was assessed using the Urinary Creatinine Detection Kit (Arbor Assays, Ann Arbor, MI, USA).

Quantification of 17- $\beta$-estradiol was performed by an enzyme-linked fluorescent assay (bioMérieux SA, Marcy l'Étoile, France) according to the manufacturer's instructions. All samples were measured in duplicate.

Inter-assay precision, coefficient of variation (CV), of these analyses were all $<20 \%$.

\section{Statistical analysis}

The normality distribution was assessed by the Kolmogorov-Smirnov test. Natural logarithms of clock gene expression, aMT6s and 17- $\beta$-estradiol levels were used for analysis as transformed values more closely approximated a normal distribution. Continuous variables were expressed as mean and standard deviation while $\log$ transformed variables were expressed as geometric mean along with $95 \%$ confidence interval $(95 \%$ CI). Student's t-test was used to test differences between DT and SW nurses. The Chi-square test was used to test dichotomous parameters. Pearson correlation test was applied to analyze relationships between continuous parameters. Multivariate linear regression analysis was used to assess clock gene expression, aMT6s, and $17-\beta$-estradiol in the different groups. Explanatory variables associated with the outcome, at a significance of $\leq 0.20$ at univariate analysis, were included as independent variables. Body mass index (BMI) and physical activity were considered as potential confounders a priori in the multivariate analysis of $17-\beta$-estradiol levels (67). Statistical significance was set at $\mathrm{P}<0.05$ and statistical tests were two-sided. Statistical Package Social Sciences (version 19) software (SPSS Inc, Chicago, IL, USA) was used for all calculations.

\section{Results}

The sociodemographic characteristics of the 116 participants are reported in table 1 . SW nurses were significantly younger $(\mathrm{P}<0.001)$, had shorter job seniority $(\mathrm{P}<0.001)$, fewer children $(\mathrm{P}=0.004)$, and performed more physical 
Table 1. Sociodemographic characteristics of daytime (DT) and shift-working (SW) nurses. [MEQ=Morningness-Eveningness Questionnaire; PSQI=Pittsburgh Sleep Quality Index; SD=standard deviation]

\begin{tabular}{|c|c|c|c|c|c|c|c|}
\hline & \multicolumn{3}{|c|}{ DT nurses $(\mathrm{N}=56)$} & \multicolumn{3}{|c|}{ SW nurses $(\mathrm{N}=60)$} & \multirow[t]{2}{*}{ P-value } \\
\hline & Mean & SD & $\%$ & Mean & SD & $\%$ & \\
\hline Age (years) & 41.5 & 4.2 & & 38.0 & 6.3 & & $<0.001$ \\
\hline Job seniority (years) & 19.5 & 4.7 & & 13.7 & 5.7 & & $<0.001$ \\
\hline Shift work seniority (years) & - & - & & 12.7 & 5.4 & & - \\
\hline $\begin{array}{l}\text { Night shift work frequency per month } \\
\text { (nights) }\end{array}$ & - & - & & 6.0 & 1.0 & & - \\
\hline Chronotype ${ }^{a}$ (MEQ score) & 57.6 & 9.0 & & 55.5 & 8.6 & & 0.201 \\
\hline Quality of sleep (PSQI score) & 5.6 & 3.0 & & 5.4 & 2.8 & & 0.711 \\
\hline Body mass index & 24.7 & 4.7 & & 24.5 & 5.1 & & 0.827 \\
\hline Physical activity (days/week) & 1.0 & 1.4 & & 1.6 & 1.3 & & 0.018 \\
\hline Alcohol drinkers (\%) & & & 37.5 & & & 33.3 & 0.781 \\
\hline Smokers (\%) & & & 33.9 & & & 31.7 & 0.957 \\
\hline Irregular menstrual cycle (\%) & & & 53.6 & & & 50.0 & 0.840 \\
\hline Offspring (number) & 1.6 & 1.0 & & 1.1 & 1.1 & & 0.004 \\
\hline Miscarriages (\%) & & & 16.1 & & & 18.3 & 0.946 \\
\hline
\end{tabular}

a A chronotype higher score is indicative of morningness preference.

activity ( $\mathrm{P}=0.018$ ) when compared to DT nurses. However, the two groups did not differ in chronotype score, quality of sleep, BMI, alcohol consumption, cigarette smoking, menstrual cycle regularity, and miscarriages.

In the analysis of circadian gene expression, a significant higher mRNA expression of $B M A L 1(\mathrm{P}=0.001)$, CLOCK $(\mathrm{P}=0.027)$, NPAS2 ( $\mathrm{P}=0.001)$, PER1 (0.025), PER2 $(\mathrm{P}=0.002), \operatorname{REVERB} \alpha(\mathrm{P}=0.007)$, and lower mRNA expression of PER3 ( $\mathrm{P}=0.029), C R Y 1(\mathrm{P}=0.006)$, CRY2 ( $\mathrm{P}=0.006)$ were observed among $\mathrm{SW}$ compared to DT nurses (table 2). Urinary aMT6s levels were not significantly different between SW and DT nurses. Significant increased serum $17-\beta$-estradiol levels $(\mathrm{P}=0.040)$ were found among SW compared to DT nurses.

Analysis of correlation did not reveal any significant relationships between circadian gene expression, aMT6s, and 17- $\beta$-estradiol levels with shift work seniority (table 3). The mRNA levels of all analyzed circadian

Table 2. Levels of clock gene expression, 6-sulphatoxymelatonin (aMT6s) and 17- $\beta$-estradiol of daytime (DT) and shift-working (SW) nurses. [GM=geometric mean; $95 \% \mathrm{Cl}=95 \%$ confidence interval]

\begin{tabular}{|c|c|c|c|c|c|}
\hline & \multicolumn{2}{|c|}{$\begin{array}{l}\text { DT nurses } \\
(\mathrm{N}=56)\end{array}$} & \multicolumn{2}{|c|}{$\begin{array}{l}\text { SW nurses } \\
(N=60)\end{array}$} & \multirow[t]{2}{*}{ P-value } \\
\hline & GM & $95 \% \mathrm{Cl}$ & GM & $95 \% \mathrm{Cl}$ & \\
\hline \multicolumn{6}{|l|}{ Clock gene expression } \\
\hline BMAL $\left(2^{-\Delta C T} \times 10^{3}\right)$ & 1.1 & $0.5-2.2$ & 5.4 & $3.4-8.6$ & 0.001 \\
\hline $\operatorname{CLOCK}\left(2^{-\triangle C T} \times 10^{3}\right)$ & 3.2 & $0.9-11.3$ & 6.0 & $2.0-17.8$ & 0.027 \\
\hline NPAS2 $\left(2^{-\Delta C T} \times 10^{3}\right)$ & 1.0 & $0.7-1.4$ & 1.9 & $1.4-2.5$ & 0.001 \\
\hline PER1 $\left(2^{-\triangle C T} \times 10^{3}\right)$ & 3.1 & $2.1-4.6$ & 4.9 & $3.2-7.3$ & 0.025 \\
\hline PER2 $\left(2^{-\triangle C T} \times 10^{3}\right)$ & 5.2 & $3.6-7.6$ & 11.0 & $8.5-14.2$ & 0.002 \\
\hline PER3 $\left(2^{-\triangle C T} \times 10^{3}\right)$ & 3.8 & $2.3-6.3$ & 2.7 & $1.8-4.1$ & 0.029 \\
\hline$C R Y 1\left(2^{-\Delta C T} \times 10^{3}\right)$ & 14.8 & $9.3-23.4$ & 9.4 & $6.6-13.4$ & 0.006 \\
\hline CRY2 $\left(2^{-\Delta C T} \times 10^{3}\right)$ & 19.1 & $10.9-33.5$ & 9.8 & $7.8-12.4$ & 0.006 \\
\hline REVERB $\alpha\left(2^{-\triangle C T} \times 10^{3}\right)$ & 8.3 & $3.9-18.0$ & 22.9 & $14.6-35.9$ & 0.007 \\
\hline aMT6s (ng/mg creatinine) & 35.2 & $28.7-43.6$ & 42.0 & $34.1-54.8$ & 0.301 \\
\hline 17- $\beta$-estradiol (pg/ml) & 41.9 & $31.8-43.7$ & 50.5 & $44.5-58.8$ & 0.040 \\
\hline
\end{tabular}

genes presented significant correlation with each other in the whole study group. BMAL1 expression is significantly correlated with physical activity while $B M A L 1$, CLOCK, NPAS2, PER1, PER2, PER3, CRY1, and CRY2 expression negatively correlated with $17-\beta$-estradiol levels. Chronotype score was found to be positively correlated with 17- $\beta$-estradiol levels; particularly the morningness-oriented chronotype was related to higher $17-\beta$-estradiol levels.

Multiple linear regression analysis taking into account age, chronotype score, physical activity, and number of offspring as covariates, confirmed an effect of shift work on gene expression of BMAL1 ( $\beta 0.21, \mathrm{P}=0.040)$, CLOCK $(\beta$ 0.35, $\mathrm{P}=0.008)$, NPAS2 $(\beta$ 0.30, $\mathrm{P}=0.012)$, PER1 ( $\beta$ 0.33, $\mathrm{P}=0.008)$, PER2 ( $\beta$ 0.19, $\mathrm{P}=0.047)$, PER3 $(\beta-0.27, \mathrm{P}=0.012), C R Y 1(\beta-0.33, \mathrm{P}=0.002), C R Y 2(\beta$ $-0.31, \mathrm{P}=0.005)$, and REVERB $\alpha(\beta 0.19, \mathrm{P}=0.045)$ (table $4)$. An effect of shift work on $17-\beta$-estradiol levels was found ( $\beta 0.32, \mathrm{P}=0.003$ ) in multiple regression analysis adjusted for age, chronotype score, BMI, physical activity and number of offspring. Moreover, the variability in $17-\beta$-estradiol levels was also significantly explained by chronotype score $(\beta 0.26, \mathrm{P}=0.011)$. Chronotype showed a significant contribution to PERI $(\beta 0.48, \mathrm{P}=0.001)$ and PER2 ( $\beta-0.22, \mathrm{P}=0.022)$ variability, while no effect was confirmed for CLOCK $(\beta-0.20, \mathrm{P}=0.110)$ and NPAS2 $(\beta$ $-0.15, \mathrm{P}=0.228)$.

\section{Discussion}

A number of studies have shown a link between shiftnight work and higher risk of breast cancer among women $(7-17,68)$. The development of breast cancer among shift workers may be the result of circadian 
Table 3. Pearson correlation between the variables examined among all participants. [BMI=body mass index; MEQ=Morningness-Eveningness Questionnaire; PSQI=Pittsburgh Sleep Quality Index]

\begin{tabular}{|c|c|c|c|c|c|c|c|c|c|c|c|}
\hline & \multicolumn{9}{|c|}{ Clock gene expression } & \multirow[t]{2}{*}{ aMT6s } & \multirow[t]{2}{*}{$17-\beta$-estradio } \\
\hline & $B M A L 1$ & CLOCK & NPAS2 & PER1 & PER2 & PER3 & CRY1 & CRY2 & $R E V E R B \alpha$ & & \\
\hline $\begin{array}{l}\text { Age } \\
\text { Job seniority }\end{array}$ & $\begin{array}{l}-0.09 \\
-0.01\end{array}$ & $\begin{array}{l}0.17 \\
0.09\end{array}$ & $\begin{array}{r}-0.10 \\
0.09\end{array}$ & $\begin{array}{r}-0.26 \\
0.09\end{array}$ & $\begin{array}{l}-0.09 \\
-0.02\end{array}$ & $\begin{array}{l}-0.04 \\
-0.09\end{array}$ & $\begin{array}{l}-0.03 \\
-0.14\end{array}$ & $\begin{array}{r}0.03 \\
-0.14\end{array}$ & $\begin{array}{l}-0.14 \\
-0.06\end{array}$ & $\begin{array}{l}0.17 \\
0.04\end{array}$ & $\begin{array}{l}0.12 \\
0.08\end{array}$ \\
\hline $\begin{array}{l}\text { Shift work seniority } \\
\text { (among SW) }\end{array}$ & 0.21 & -0.03 & 0.01 & 0.25 & 0.20 & 0.14 & 0.15 & 0.13 & 0.20 & 0.15 & 0.15 \\
\hline $\begin{array}{l}\text { Chronotype (MEQ } \\
\text { score) a }\end{array}$ & -0.07 & $-0.27^{b}$ & $-0.24^{b}$ & $0.38^{b}$ & $-0.25^{b}$ & -0.03 & 0.01 & -0.02 & -0.09 & 0.10 & $0.27^{\mathrm{b}}$ \\
\hline $\begin{array}{l}\text { Quality of sleep } \\
\text { (PSQI score) }\end{array}$ & -0.02 & 0.24 & -0.05 & -0.03 & 0.02 & 0.17 & -0.04 & -0.02 & -0.09 & -0.03 & 0.16 \\
\hline $\mathrm{BMI}$ & 0.11 & -0.03 & -0.05 & -0.06 & 0.05 & 0.06 & 0.15 & 0.05 & 0.06 & 0.01 & 0.02 \\
\hline Physical activity & $0.28^{b}$ & -0.18 & 0.14 & -0.13 & 0.08 & 0.08 & 0.07 & 0.02 & 0.17 & 0.13 & 0.07 \\
\hline $\begin{array}{l}\text { Offspring number } \\
\text { Clock gene expressi }\end{array}$ & -0.10 & 0.11 & 0.14 & 0.29 & 0.10 & 0.07 & 0.03 & 0.03 & -0.10 & 0.14 & -0.05 \\
\hline BMAL1 & 1 & $0.44^{b}$ & $0.57^{\mathrm{b}}$ & $0.30^{\mathrm{b}}$ & $0.60^{\mathrm{b}}$ & $0.64^{b}$ & $0.69^{b}$ & $0.56^{b}$ & $0.85^{b}$ & 0.04 & $-0.20^{b}$ \\
\hline CLOCK & $0.44^{b}$ & 1 & $0.47^{\mathrm{b}}$ & $0.21^{\mathrm{b}}$ & $0.46^{b}$ & $0.45^{b}$ & $0.33^{b}$ & $0.25^{b}$ & $0.54^{b}$ & -0.14 & $-0.21^{b}$ \\
\hline NPAS2 & $0.57^{b}$ & $0.47^{\mathrm{b}}$ & 1 & $0.34^{b}$ & $0.78^{b}$ & $0.45^{b}$ & $0.42^{b}$ & $0.50^{\mathrm{b}}$ & $0.65^{b}$ & 0.19 & $-0.23^{b}$ \\
\hline PER1 & $0.30^{\mathrm{b}}$ & $0.21^{\mathrm{b}}$ & $0.34^{\mathrm{b}}$ & 1 & $0.24^{b}$ & $0.49^{b}$ & $0.18^{b}$ & $0.26^{b}$ & $0.61^{\mathrm{b}}$ & -0.09 & 0.02 \\
\hline PER2 & $0.60^{\mathrm{b}}$ & $0.46^{b}$ & $0.78^{b}$ & $0.24^{b}$ & 1 & $0.47^{b}$ & $0.44^{b}$ & $0.43^{b}$ & $0.54^{\mathrm{b}}$ & 0.12 & $-0.33^{b}$ \\
\hline PER3 & $0.64^{b}$ & $0.45^{b}$ & $0.45^{b}$ & $0.49^{b}$ & $0.47^{b}$ & 1 & $0.79^{b}$ & $0.66^{b}$ & $0.73^{b}$ & 0.19 & $-0.27^{b}$ \\
\hline$C R Y 1$ & $0.69^{b}$ & $0.33^{b}$ & $0.42^{\mathrm{b}}$ & $0.18^{b}$ & $0.44^{b}$ & $0.79^{b}$ & 1 & $0.71^{\mathrm{b}}$ & $0.69^{b}$ & 0.06 & $-0.29^{b}$ \\
\hline CRY2 & $0.56^{\mathrm{b}}$ & $0.25^{b}$ & $0.47^{b}$ & $0.26^{b}$ & $0.43^{b}$ & $0.66^{\mathrm{b}}$ & $0.71^{\mathrm{b}}$ & 1 & $0.63^{b}$ & 0.06 & $-0.20^{b}$ \\
\hline REVERB $\alpha$ & $0.85^{b}$ & $0.54^{b}$ & $0.65^{b}$ & $0.61^{\mathrm{b}}$ & $0.54^{b}$ & $0.73^{b}$ & $0.69^{b}$ & $0.63^{b}$ & 1 & 0.19 & -0.14 \\
\hline aMT6s & 0.04 & -0.14 & 0.19 & -0.09 & 0.12 & 0.19 & 0.06 & 0.06 & 0.20 & 1 & 0.12 \\
\hline $17-\beta$-estradiol & $-0.20^{b}$ & $-0.21^{b}$ & $-0.23^{b}$ & 0.02 & $-0.33^{b}$ & $-0.27^{b}$ & $-0.29 b$ & $-0.20^{b}$ & -0.14 & 0.12 & 1 \\
\hline
\end{tabular}

${ }^{a} A$ chronotype higher score is indicative of morningness preference.

b $\mathrm{P}<0.05$.

Table 4. Effect of shift work and chronotype on clock gene expression, aMT6s and 17- $\beta$-estradiol, adjusted for covariates. ${ }^{a}$ Results of multivariate linear analysis.

\begin{tabular}{|c|c|c|c|c|c|}
\hline & \multirow{2}{*}{$\begin{array}{c}\mathrm{R} \\
\text { of the } \\
\text { model }\end{array}$} & \multicolumn{2}{|c|}{ Shift work } & \multicolumn{2}{|c|}{ Chronotype } \\
\hline & & $\beta$ & P-value & $\beta$ & P-value \\
\hline \multicolumn{6}{|c|}{ Clock gene expression } \\
\hline BMAL1 & 0.35 & 0.21 & 0.040 & -0.21 & 0.839 \\
\hline CLOCK & 0.39 & 0.35 & 0.008 & -0.20 & 0.110 \\
\hline NPAS2 & 0.30 & 0.30 & 0.012 & -0.15 & 0.228 \\
\hline PER1 & 0.57 & 0.33 & 0.008 & 0.48 & 0.001 \\
\hline PER2 & 0.31 & 0.19 & 0.047 & -0.22 & 0.022 \\
\hline PER3 & 0.30 & -0.27 & 0.012 & -0.07 & 0.485 \\
\hline CRY1 & 0.32 & -0.33 & 0.002 & -0.02 & 0.886 \\
\hline CRY2 & 0.29 & -0.31 & 0.005 & -0.07 & 0.519 \\
\hline REVERB $\alpha$ & 0.30 & 0.19 & 0.045 & -0.02 & 0.853 \\
\hline aMT6s & 0.30 & 0.18 & 0.130 & -0.07 & 0.534 \\
\hline 17- $\beta$-estradiol & 0.41 & 0.32 & 0.003 & 0.26 & 0.011 \\
\hline
\end{tabular}

a Adjusted for age, physical activity and number of offspring (clock gene expression and aMT6s). Adjusted for age, BMI, physical activity and number of offspring (17- $\beta$-estradiol).

rhythms alterations $(2,69)$. The clock genes are important regulators of circadian rhythms affecting cancer susceptibility through biological pathways that regulate DNA damage and repair, carcinogen metabolism and/or detoxification, cell growth and cell death (70).

In this study the analysis of participants' sociodemographic characteristics showed some significant dif- ferences among groups. Specifically, SW nurses were significantly younger, had lower job seniority, engaged more often in physical exercise, and had fewer children. However, these findings were expected, since older nurses with greater job seniority tend to be assigned to daytime work by hospital management $(4,71)$. The greater proportion of SW nurses taking exercise may be related to their younger age and a work schedule enabling a better organization of leisure time. However, the parameters that showed statistically different results among the groups were included in the multivariate analysis as covariates.

In this study the investigation of clock gene expression resulted in a greater expression of the BMAL1, CLOCK, NPAS2, PER1, PER2, and REVERB $\alpha$ genes and lower levels of PER3, CRY1, and CRY2 genes among SW compared to DT nurses. These findings suggest an influence of the SW in the regulation of circadian rhythm of peripheral clock gene expression.

All analyzed circadian genes presented significant correlations with each other in the whole study group (table 3). The correlation between all circadian studied genes confirmed the dependence of circadian genes in peripheral tissue as they are linked to the same transcriptional-translational feedback loops.

To our knowledge, few studies have been performed on circadian gene mRNA expression among shift work- 
ers (72-76). In a study where SW nurses were analyzed at the end of the night shift, no differences were reported in clock gene expression (72). Similarly, Reszka and co-workers (75) found no statistically significant changes of investigated circadian genes among SW nurses after adjusting for the hour of blood collection. The time of sampling should be carefully taken into account in studies analyzing peripheral levels of clock gene expression since they fluctuate naturally in a circadian fashion. Moreover, clock genes expression may be also affected by a number of internal and external cues (77-80). Shift workers experience exposure to artificial light and sleep deprivation during the night shift thus, the work shift preceding the sampling should be considered since it can influence the results. In this study, both SW and DT nurses were analyzed at beginning of the morning shift after a day off in order to prevent findings of acute alterations associated with the night shift. The shift work influence on peripheral clock gene expression evidenced in this study cannot be generalized since it refers to the specific sampling time point studied. Nevertheless, the results of this study should be carefully considered since an altered clock gene expression has been demonstrated in breast cancer $(23,81-83)$ and other disorders (24-26) associated with shift work.

Inhibition of the melatonin synthesis has also been suggested as a possible biological mechanism implicated in increased risk of breast cancer among night-shift workers $(1,39)$. In this study, no differences in average aMT6s levels were reported among SW compared to DT nurses (table 2), and no correlation was found between aMT6s and job seniority. These results differ from previous findings that reported low aMT6s levels among SW nurses analyzed at the end of the night shift after having experienced artificial light exposure and sleep deprivation (72). In this study, the aMT6s results of SW nurses were likely to be affected by the sleep on the night before sampling. Considering the low number (mean $=6.0$ ) of participant's night shifts per month in this study, these results are in line with a previous study where a decrease of aMT6s was only found to be associated with $\geq 8$ night shifts per month (41). The role of external factors such as age, physical activity, and alcohol and tobacco consumption in promoting a reduction in melatonin production is controversial (84-90). However, no correlation between aMT6s and these factors was observed in this study.

The exposure to light at night, as that experienced by SW nurses during night shifts, is supposed to not only suppress melatonin production but also be paralleled by an increase in estrogen levels, which in turn may induce a higher risk of breast cancer among women who work shifts $(38,39,91)$. The analysis of $17-\beta$-estradiol among participating SW nurses evidenced significantly higher levels compared to DT nurses and the effect of SW on $17-\beta$-estradiol levels persisted also after correction for known confounding factors (67). No significant correlation was seen between $17-\beta$-estradiol and urinary aMT6s levels and between 17- $\beta$-estradiol levels and SW seniority accordingly with other studies $(45,46,67) . B M A L 1$, CLOCK, NPAS2, PER2, PER3, CRY1, and CRY2 gene expression negatively correlated with 17- $\beta$-estradiol levels. These correlations support a possible link between $17-\beta$-estradiol and circadian biological clock $(92,93)$.

Recently it was found that women with a morning chronotype preference who worked on night shifts tended to have a higher risk of breast cancer than those with a evening chronotype preference (33). Interestingly the results of this study indicated that morningnessoriented chronotype was correlated with high serum $17-\beta$-estradiol levels also after correction for covariates. Chronotype was also an independent factor for PERI and PER2 gene expression. This finding supports the role of chronotype in the adaptation of the circadian system to shift work as well as the regulation of clock gene expression $(32,94)$. The selected small sample size is the main limitation of this study and limits the generalizability of the results. However, the strength of the inclusion criteria of female participants, and the timing of sampling, constituted the necessary conditions to obtain comparable results. Further studies on larger populations are warranted to confirm our findings.

In conclusion, this study indicates that rotating SW nurses show an alteration in peripheral clock gene expression and 17- $\beta$-estradiol levels at the beginning of the morning shift after a day off. SW including night work, as well as chronotype, is related to biological clock regulation and 17- $\beta$-estradiol levels that may result in increased risk of breast cancer.

\section{Acknowledgment}

This study was supported in part by grants from the Italian Institute of Insurance against Professional Illness and Injuries (INAIL). The authors thank Dr Matteo Marconi for his kind aid in data collection and Mrs Megan Conner for her revision of the English language.

\section{References}

1. Costa G, Haus E, Stevens R. Shift work and cancerconsiderations on rationale, mechanisms, and epidemiology. Scand J Work Environ Health. 2010;36:163-179. http://dx.doi. org/10.5271/sjweh.2899

2. Stevens RG. Circadian disruption and breast cancer: from 
melatonin to clock genes. Epidemiology. 2005;16: 254-258. http://dx.doi.org/10.1097/01.ede.0000152525.21924.54

3. Di Milia L, Waage S, Pallesen S, Bjorvatn B. Shift work disorder in a random population sample--prevalence and comorbidities. PLoS One. 2013. http://dx.doi.org/10.1371/ journal.pone.0055306

4. Copertaro A, Bracci M, Barbaresi M, Santarelli L. Assessment of cardiovascular risk in shift healthcare workers. Eur J Cardiovasc Prev Rehabil. 2008;15:224-229. http://dx.doi. org/10.1097/HJR.0b013e3282f364c0

5. Flo E, Pallesen S, Magerøy N, Moen BE, Grønli J, Hilde Nordhus I, et al. Shift work disorder in nurses--assessment, prevalence and related health problems. PLoS One 2012. http://dx.doi.org/10.1371/journal.pone.0033981

6. International Agency for Research on Cancer (IARC). Painting, firefighting, and shiftwork. Lyon: IARC; 2010. IARC Monographs on the evaluation of the carcinogenic risks of chemicals to humans, vol 98.

7. Schernhammer ES, Laden F, Speizer FE, Willett WC, Hunter DJ, Kawachi I, et al. Rotating night shifts and risk of breast cancer in women participating in the nurses' health study. J Natl Cancer Inst. 2001;93:1563-1568. http://dx.doi. org/10.1093/jnci/93.20.1563

8. Davis S, Mirick DK, Stevens RG. Night shift work, light at night, and risk of breast cancer. J Natl Cancer Inst. 2001;93:1557-1562. http://dx.doi.org/10.1093/ jnci/93.20.1557

9. Hansen J. Increased breast cancer risk among women who work predominantly at night. Epidemiology 2001;12:74-77. http://dx.doi.org/10.1097/00001648-200101000-00013

10. Schernhammer ES, Kroenke CH, Laden F, Hankinson SE. Night work and risk of breast cancer. Epidemiology 2006;17:108111. http://dx.doi.org/10.1097/01.ede.0000190539.03500.c1

11. Hansen J, Lassen CF. Nested case-control study of night shift work and breast cancer risk among women in the Danish military. Occup Environ Med. 2012;69:551-556. http://dx.doi. org/10.1136/oemed-2011-100240

12. Grundy A, Richardson H, Burstyn I, Lohrisch C, Sengupta SK, Lai AS, et al. Increased risk of breast cancer associated with long-term shift work in Canada. Occup Environ Med. 2013;70:831-838. http://dx.doi.org/10.1136/ oemed-2013-101482

13. Wang F, Yeung KL, Chan WC, Kwok CC, Leung SL, Wu C, et al. A meta-analysis on dose-response relationship between night shift work and the risk of breast cancer. Ann Oncol. 2013;24:2724-2732. http://dx.doi.org/10.1093/annonc/ mdt 283

14. Pesch B, Harth V, Rabstein S, Baisch C, Schiffermann M, Pallapies D, et al. Night work and breast cancer - results from the German GENICA study. Scand J Work Environ Health. 2010;36:134-141. http://dx.doi.org/10.5271/sjweh.2890

15. Rabstein S, Harth V, Pesch B, Pallapies D, Lotz A, Justenhoven $\mathrm{C}$, et al. Night work and breast cancer estrogen receptor status--results from the German GENICA study. Scand J Work Environ Health. 2013;39:448-455. http://dx.doi.org/10.5271/ sjweh. 3360
16. Knutsson A, Alfredsson L, Karlsson B, Akerstedt T, Fransson EI, Westerholm P, et al. Breast cancer among shift workers: results of the WOLF longitudinal cohort study. Scand J Work Environ Health. 2013;39:170-177. http://dx.doi.org/10.5271/ sjweh.3323

17. Bonde JP, Hansen J, Kolstad HA, Mikkelsen S, Olsen JH, Blask DE, et al. Work at night and breast cancer--report on evidence-based options for preventive actions. Scand J Work Environ Health. 2012;38:380-390. http://dx.doi.org/10.5271/ sjweh.3282

18. Dibner C, Schibler U, Albrecht U. The mammalian circadian timing system: organization and coordination of central and peripheral clocks. Annu Rev Physiol. 2010;72:517-549. http:// dx.doi.org/10.1146/annurev-physiol-021909-135821

19. Slat E, Freeman GM Jr, Herzog ED. The clock in the brain: neurons, glia, andnetworks in daily rhythms. Handb Exp Pharmacol. 2013;217:105-123. http://dx.doi. org/10.1007/978-3-642-25950-0_5.

20. Brown SA, Azzi A. Peripheral circadian oscillators in mammals. Handb Exp Pharmacol. 2013;217:45-66. http:// dx.doi.org/10.1007/978-3-642-25950-0_3

21. Reppert SM, Weaver DR. Coordination of circadian timing in mammals. Nature. 2002;418: 935-941. http://dx.doi. org/10.1038/nature00965

22. Lowrey PL, Takahashi JS. Mammalian circadian biology: elucidating genome-wide levels of temporal organization. Annu Rev Genomics Hum Genet. 2004;5:407-441. http:// dx.doi.org/10.1146/annurev.genom.5.061903.175925

23. Rana S, Mahmood S. Circadian rhythm and its role in malignancy. J Circadian Rhythms. 2010;8:3. http://dx.doi. org/10.1186/1740-3391-8-3

24. Gómez-Abellán P, Hernández-Morante JJ, Luján JA, Madrid JA, Garaulet M. Clock genes are implicated in the human metabolic syndrome. Int J Obes (Lond). 2008;32:121-128. http://dx.doi.org/10.1038/sj.ijo.0803689

25. Ando H, Ushijima K, Kumazaki M, Eto T, Takamura T, Irie $\mathrm{S}$, et al. Associations of metabolic parameters and ethanol consumption with messenger RNA expression of clock genes in healthy men. Chronobiol Int. 2010; 27:194-203. http:// dx.doi.org/10.3109/07420520903398617

26. Woon PY, Kaisaki PJ, Bragança J, Bihoreau MT, Levy JC, Farrall M et al. Aryl hydrocarbon receptor nuclear translocatorlike (BMAL1) is associated with susceptibility to hypertension and type 2 diabetes. Proc Natl Acad Sci U S A. 2007; 104 :14412-14417. http://dx.doi.org/10.1073/pnas.0703247104

27. Stevens RG. Artificial lighting in the industrialized world: circadian disruption and breast cancer. Cancer Causes Control. 2006;17:501-507. http://dx.doi.org/10.1007/s10552-0059001-x

28. Hida A, Kitamura S, Ohsawa Y, Enomoto M, Katayose Y, Motomura Y, et al. In vitro circadian period is associated with circadian/sleep preference. Sci Rep. 2013;3:2074. http:// dx.doi.org/10.1038/srep02074

29. Osland TM, Bjorvatn BR, Steen VM, Pallesen Sl. Association study of a variable-number tandem repeat polymorphism in the 
clock gene PERIOD3 and chronotype in Norwegian university students. Chronobiol Int. 2011;28:764-70. http://dx.doi.org/10 $.3109 / 07420528.2011 .607375$

30. Brown SA, Kunz D, Dumas A, Westermark PO, Vanselow K, Tilmann-Wahnschaffe A, Herzel H, Kramer A. Molecular insights into human daily behavior. Proc Natl Acad Sci U S A. 2008;105:1602-1607. http://dx.doi.org/10.1073/ pnas. 0707772105

31. Sack RL, Auckley D, Auger RR, Carskadon MA, Wright KP Jr, Vitiello MV, et al. Circadian rhythm sleep disorders: part I, basic principles, shift work and jet lag disorders. An American Academy of Sleep Medicine review. Sleep. 2007;30:1460-1483.

32. Gamble KL, Motsinger-Reif AA, Hida A, Borsetti HM, Servick SV, Ciarleglio CM, et al. Shift work in nurses: contribution of phenotypes and genotypes to adaptation. PLoS One. 2011. http://dx.doi.org/10.1371/journal.pone.0018395

33. Hansen J, Lassen CF. Nested case-control study of night shift work and breast cancer risk among women in the Danish military. Occup Environ Med. 2012;69:551-556. http://dx.doi. org/10.1136/oemed-2011-100240

34. Schernhammer ES, Schulmeister K. Melatonin and cancer risk: does light at night compromise physiologic cancer protection by lowering serum melatonin levels? $\mathrm{Br} \mathrm{J}$ Cancer. 2004;90: 941- 943. http://dx.doi.org/10.1038/sj.bjc.6601626

35. Stevens RG, Blask DE, Brainard GC, Hansen J, Lockley SW, Provencio I, et al. Meeting report: the role of environmental lighting and circadian disruption in cancer and other diseases. Environ Health Perspect. 2007;115:1357-62. http://dx.doi. org/10.1289/ehp.10200

36. Mirick DK, Davis S. Melatonin as a biomarker of circadian dysregulation. Cancer Epidemiol Biomarkers Prev. 2008;17:3306-3313. http://dx.doi.org/10.1158/1055-9965. EPI-08-0605

37. Cos S, GonzálezA, Martínez-Campa C, Mediavilla MD, AlonsoGonzález C, Sanchez- Barceló EJ. Melatonin as a selective estrogen enzyme modulator. Curr Cancer Drug Targets. 2008;8: 691-702. http://dx.doi.org/10.2174/156800908786733469

38. Nelson R. Steroidal oestrogens added to list of known human carcinogens. Lancet. 2002;360: 2053. http://dx.doi. org/10.1016/S0140-6736(02)12045-9

39. Stevens RG. Working against our endogenous circadian clock: Breast cancer and electric lighting in the modern world. Mutat Res. 2009; 680:106-108. http://dx.doi.org/10.1016/j. mrgentox.2009.08.004

40. Ni Ji BT, Gao YT, Shu XO, Yang G, Yu K, Xue SZ, et al. Nightshift work job exposure matrices and urinary 6-sulfatoxymelatonin levels among healthy Chinese women. Scand J Work Environ Health. 2012;38:553-559. http://dx.doi. org/10.5271/sjweh.3322

41. Peplonska B, Bukowska A, Gromadzinska J, Sobala W, Reszka E, Lie JA, et al. Night shift work characteristics and 6-sulfatoxymelatonin (MT6s) in rotating night shift nurses and midwives. Occup Environ Med. 2012;69:339-346. http:// dx.doi.org/10.1136/oemed-2011-100273

42. Davis S, Mirick DK, Chen C, Stanczyk FZ. Night shift work and hormone levels in women. Cancer Epidemiol Biomarkers Prev; 2012;21:609-618. http://dx.doi.org/10.1158/10559965.EPI-11-1128

43. Marie Hansen A, Helene Garde A, Hansen J. Diurnal urinary 6-sulfatoxymelatonin levels among healthy Danish nurses during work and leisure time. Chronobiol Int. 2006;23:12031215 http://dx.doi.org/10.1080/07420520601100955

44. Grundy A, Tranmer J, Richardson H, Graham CH, Aronson KJ. The influence of light at night exposure on melatonin levels among Canadian rotating shift nurses. Cancer Epidemiol Biomarkers Prev. 2011;20:2404-2412. http://dx.doi. org/10.1158/1055-9965.EPI-11-0427

45. Yamauchi H. Effects of night work on urinary excretion rates of 6sulfatoxymelatonin, norepinephrine and estriol in pregnant women. Ind Health. 2004;42:268-276. http://dx.doi. org/10.2486/indhealth. 42.268

46. Schernhammer ES, Rosner B, Willett WC, Laden F, Colditz GA, Hankinson SE. Epidemiology of urinary melatonin in women and its relation to other hormones and night work. Cancer Epidemiol Biomarkers Prev. 2004;13: 936-943.

47. Davis S, Mirick DK, Chen C, Stanczyk FZ. Night shift work and hormone levels in women. Cancer Epidemiol Biomarkers Prev; 2012;21:609-618. http://dx.doi.org/10.1158/10559965.EPI-11-1128

48. Marie Hansen A, Helene Garde A, Hansen J. Diurnal urinary 6-sulfatoxymelatonin levels among healthy Danish nurses during work and leisure time. Chronobiol Int. 2006;23:12031215. http://dx.doi.org/10.1080/07420520601100955

49. Grundy A, Tranmer J, Richardson H, Graham CH, Aronson KJ. The influence of light at night exposure on melatonin levels among Canadian rotating shift nurses. Cancer Epidemiol Biomarkers Prev. 2011;20:2404-2412. http://dx.doi. org/10.1158/1055-9965.EPI-11-0427

50. Schernhammer ES, Kroenke CH, Dowsett M, Folkerd E, Hankinson SE. Urinary 6-sulfatoxymelatonin levels and their correlations with lifestyle factors and steroid hormone levels. J Pineal Res. 2006;40:116-124. http://dx.doi.org/10.1111/ j.1600-079X.2005.00285.x

51. Nagata C, Nagao Y, Yamamoto S, Shibuya C, Kashiki Y, Shimizu H. Light exposure at night, urinary 6-sulfatoxymelatonin, and serum estrogens and androgens in postmenopausal Japanese women. Cancer Epidemiol Biomarkers Prev. 2008;17:14181423. http://dx.doi.org/10.1158/1055-9965.EPI-07-0656

52. Small CM, Marcus M, Sherman SL, Sullivan AK, Manatunga AK, Feigelson HS. CYP17 genotype predicts serum hormone levels among pre-menopausal women. Hum Reprod. 2005;20:2162-2167. http://dx.doi.org/10.1093/humrep/ dei054

53. Eliassen AH, Missmer SA, Tworoger SS, Spiegelman D, Barbieri RL, Dowsett M, et al. Endogenous steroid hormone concentrations and risk of breast cancer among premenopausal women. J Natl Cancer Inst. 2006;98:1406-1415. http://dx.doi. org/10.1093/jnci/djj376

54. Buysse DJ, Reynolds CF 3rd, Monk TH, Berman SR, Kupfer DJ. The Pittsburgh Sleep Quality Index: a new 
instrument for psychiatric practice and research. Psychiatry Res. 1989;28:193-213. http://dx.doi.org/10.1016/01651781(89)90047-4

55. Horne JA, Ostberg O. A self-assessment questionnaire to determine morningness eveningness in human circadian rhythms. Int J Chronobiol. 1976;4:97-110.

56. Taillard J, Philip P, Chastang JF, Bioulac B. Validation of Horne and Ostberg morningness-eveningness questionnaire in a middle-aged population of French workers. J Biol Rhythms. 2004;19:76-86. http://dx.doi.org/10.1177/0748730403259849

57. Bajaj A, Rosner B, Lockley SW, Schernhammer ES. Validation of a light questionnaire with real-life photopic illuminance measurements: the Harvard Light Exposure Assessment questionnaire. Cancer Epidemiol Biomarkers Prev. 2011;20:1341-9. http://dx.doi.org/10.1158/1055-9965. EPI-11-0204

58. Chung MH, Chang FM, Yang CC, Kuo TB, Hsu N. Sleep quality and morningness-eveningness of shift nurses. J Clin Nurs. 2009;18:279-84. http://dx.doi.org/10.1111/j.13652702.2007.02160.x

59. Yazdi Z, Sadeghniiat-Haghighi K, Javadi AR, Rikhtegar G. Sleep quality and insomnia in nurses with different circadian chronotypes: Morningness and eveningness orientation. Work. 2013; Epub ahead of print.

60. Hsing AW, Meyer TE, Niwa S, Quraishi SM, Chu LW. Measuring serum melatonin in epidemiologic studies. Cancer Epidemiol Biomarkers Prev. 2010;19:932-7. http://dx.doi. org/10.1158/1055-9965.EPI-10-0004

61. Graham C, Cook MR, Kavet R, Sastre A, Smith DK. Prediction of nocturnal plasma melatonin from morning urinary measures. J Pineal Res. 1998 May;24:230-8. http://dx.doi. org/10.1111/j.1600-079X.1998.tb00538.x

62. Peplonska B, Bukowska A, Sobala W, Reszka E, Gromadzinska J, Wasowicz W, et al. Rotating night shift work and mammographic density. Cancer Epidemiol Biomarkers Prev. 2012;21:1028-37. http://dx.doi.org/10.1158/1055-9965.EPI12-0005

63. Davis S, Kaune WT, Mirick DK, Chen C, Stevens RG. Residential magnetic fields, light-at-night, and nocturnal urinary 6-sulfatoxymelatonin concentration in women. Am J Epidemiol. 2001;154:591-600. http://dx.doi.org/10.1093/ aje/154.7.591

64. Fernandez B, Malde JL, Montero A, Acu-a D. Relationship between adenohypophyseal and steroid hormones and variations in serum and urinary melatonin levels during the ovarian cycle, perimenopause and menopause in healthy women. J Steroid Biochem. 1990;35:257-262. http://dx.doi. org/10.1016/0022-4731(90)90282-W

65. Hsing AW, Meyer TE, Niwa S, Quraishi SM, Chu LW. Measuring serum melatonin in epidemiologic studies. Cancer Epidemiol Biomarkers Prev. 2010;19:932-937. http://dx.doi. org/10.1158/1055-9965.EPI-10-0004

66. Graham C, Cook MR, Kavet R, Sastre A, Smith DK. Prediction of nocturnal plasma melatonin from morning urinary measures. J Pineal Res. 1998;24:230-238. http://dx.doi. org/10.1111/j.1600-079X.1998.tb00538.x
67. Langley AR, Graham CH, Grundy AL, Tranmer JE, Richardson H, Aronson KJ. A cross-sectional study of breast cancer biomarkers among shift working nurses. BMJ Open. 2012. http://dx.doi.org/10.1136/bmjopen-2011-000532

68. Leonardi GC, Rapisarda V, Marconi A, Scalisi A, Catalano F, Proietti L, et al. Correlation of the risk of breast cancer and disruption of the circadian rhythm (Review). Oncol Rep. 2012;28: 418-428.

69. Kelleher FC, Rao A, Maguire A. Circadian molecular clocks and cancer. Cancer Lett. 2014;342:9-18. http://dx.doi. org/10.1016/j.canlet.2013.09.040

70. Zmrzljak UP, Rozman D. Circadian regulation of the hepatic endobiotic and xenobiotic detoxification pathways: the time matters. Chem Res Toxicol. 2012;25:811-824. http://dx.doi. org/10.1021/tx200538r

71. Gold DR, Rogacz S, Bock N, Tosteson TD, Baum TM, Speizer FE, et al. Rotating shift work, sleep, and accidents related to sleepiness in hospital nurses. Am J Public Health. 1992;82:1011-1014. http://dx.doi.org/10.2105/ AJPH.82.7.1011

72. Bracci M, Copertaro A, Manzella N, Staffolani S, Strafella E, Nocchi L, et al. Influence of night-shift and napping at work on urinary melatonin, $17-\beta$-estradiol and clock gene expression in pre-menopausal nurses. J Biol Regul Homeost Agents. 2013;27:267-274.

73. James FO, Cermakian N, Boivin DB. Circadian rhythms of melatonin, cortisol, and clock gene expression during simulated night shift work. Sleep. 2007;30:1427-1436.

74. Ando H, Ushijima K, Kumazaki M, , Takamura T, Yokota N, Saito $\mathrm{T}$, et al. Influence of age on clock gene expression in peripheral blood cells of healthy women. J Gerontol A Biol Sci Med Sci. 2010;65:9-13. http://dx.doi.org/10.1093/gerona/ glp 160

75. Reszka E, Peplonska B, Wieczorek E, Sobala W, Bukowska A, Gromadzinska J, et al. Circadian gene expression in peripheral blood leukocytes of rotating night shift nurses. Scand J Work Environ Health. 2013;39:187-94. http://dx.doi.org/10.5271/ sjweh.3303

76. Akashi M, Soma H, Yamamoto T, Tsugitomi A, Yamashita S, Yamamoto T, Nishida E, Yasuda A, Liao JK, Node K. Noninvasive method for assessing the human circadian clock using hair follicle cells. Proc Natl Acad Sci U S A. 2010;107:15643-8. http://dx.doi.org/10.1073/pnas.1003878107

77. Ackermann K, Plomp R, Lao O, Middleton B, Revell VL, Skene DJ, Kayser M. Effect of sleep deprivation on rhythms of clock gene expression and melatonin in humans. Chronobiol Int. 2013;30:901-909. http://dx.doi.org/10.3109/07420528.2 013.784773

78. Stevens RG. Circadian disruption and breast cancer: from melatonin to clock genes. Epidemiology. 2005;16:254-258. http://dx.doi.org/10.1097/01.ede.0000152525.21924.54

79. Balsalobre A, Brown SA, Marcacci L, Tronche F, Kellendonk C, Reichardt HM, Schütz G, Schibler U. Resetting of circadian time in peripheral tissues by glucocorticoid signaling. Science. 2000;289:2344-2347. http://dx.doi.org/10.1126/ science.289.5488.2344 
80. Manzella N, Bracci M, Staffolani S, Strafella E, Rapisarda V, Valentino M, Amati M, Copertaro A, Santarelli L. Styrene altered clock gene expression in serum-shocked cultured human fibroblasts. Biosci Biotechnol Biochem. 2013;77:12961298. http://dx.doi.org/10.1271/bbb.120944

81. Chunhui Yi, Lina Mu, Irene A, Sochirca O, Arisio R, Yu H, et al. The circadian gene NPAS2 is a novel prognostic biomarker for breast cancer. Breast Cancer Res Treat. 2010;120: 663-669. http://dx.doi.org/10.1007/s10549-009-0484-0

82. Winter SL, Bosnoyan-Collins L, Pinnaduwage D, Andrulis IL. Expression of the circadian clock genes Per1 and Per2 in sporadic and familial breast tumors. Neoplasia. 2007;9: 797-800. http://dx.doi.org/10.1593/neo.07595

83. Zienolddiny S, Haugen A, Lie JA, Kjuus H, Anmarkrud KH, Kjærheim K. Analysis of polymorphisms in the circadianrelated genes and breast cancer risk in Norwegian nurses working night shifts. Breast Cancer Res. 2013;15:R53. Epub ahead of print. http://dx.doi.org/10.1186/bcr3445

84. Dumont M, Lanctôt V, Cadieux-Viau R, Paquet J. Melatonin production and light exposure of rotating night workers. Chronobiol Int. 2012;29:203-210. http://dx.doi.org/10.3109 /07420528.2011.647177

85. Skrinar GS, Bullen BA, Reppert SM, Peachey SE, Turnbull BA, McArthur JW. Melatonin response to exercise training in women. J Pineal Res. 1989;7:185-194. http://dx.doi. org/10.1111/j.1600-079X.1989.tb00666.x

86. Kennaway DJ, Lushington K, Dawson D, Lack L, van den Heuvel C, Rogers N. Urinary 6-sulfatoxymelatonin excretion and aging: new results and a critical review of the literature. J Pineal Res. 1999; 27:210-220. http://dx.doi.org/10.1111/ j.1600-079X.1999.tb00617.x

87. Zeitzer JM, Daniels JE, Duffy JF, Klerman EB, Shanahan TL, Dijk DJ, et al. Do plasma melatonin concentrations decline with age? Am J Med. 1999;107:432-436. http://dx.doi. org/10.1016/S0002-9343(99)00266-1
88. Escames G, Ozturk G, Ba-o-Otálora B, Pozo MJ, Madrid JA, Reiter RJ, et al. Exercise and melatonin in humans: reciprocal benefits. J Pineal Res. 2012;52:1-11. http://dx.doi. org/10.1111/j.1600-079X.2011.00924.x

89. Stevens RG, Davis S, Mirick DK, Kheifets L, Kaune W. Alcohol consumption and urinary concentration of 6-sulfatoxymelatonin in healthy women. Epidemiology. 2000; 11:660-665. http://dx.doi.org/10.1097/00001648200011000-00008

90. Grundy A, Sanchez M, Richardson H, Tranmer J, Borugian M, Graham CH, et al. Light intensity exposure, sleep duration, physical activity, and biomarkers of melatonin among rotating shift nurses. Chronobiol Int. 2009;26:1443-1461. http:// dx.doi.org/10.3109/07420520903399987

91. Stevens RG. Electric power use and breast cancer: a hypothesis. Am J Epidemiol. 1987;125:556-561.

92. Rossetti S, Esposito J, Corlazzoli F, Gregorski A, Sacchi N. Entrainment of breast (cancer) epithelial cells detects distinct circadian oscillation patterns for clock and hormone receptor genes. Cell Cycle. 2012;11:350-360. http://dx.doi. org/10.4161/cc.11.2.18792

93. Nakamura TJ, Sellix MT, Kudo T, Nakao N, Yoshimura T, Ebihara S, Colwell CS, Block GD. Influence of the estrous cycle on clock gene expression in reproductive tissues: effects of fluctuating ovarian steroid hormone levels. Steroids. 2010;75:203-212. http://dx.doi.org/10.1016/j. steroids.2010.01.007

94. Nováková M, Sládek M, Sumová A. Human chronotype is determined in bodily cells under real-life conditions. Chronobiol Int. 2013;30:607-617. http://dx.doi.org/10.3109 /07420528.2012.754455.

Received for publication: October 192013 